\title{
Some post-equilibrium reactions in kimberlite-derived eclogites
}

\author{
J.B.Dawson \& S.L.Harley \\ School of Geosciences, University of Edinburgh EH9 3JW, UK
}

Eclogite xenoliths found in kimberlite intrusions are coarse-grained, mainly bimineralic rocks consisting primarily of garnet and clinopyroxene but sometimes containing rarer phases such as rutile, diamond, coesite, sanidine, orthopyroxene, kyanite and corundum, some indicative of an ultra-high pressure origin; the modern concensus is that most represent subducted oceanic crust (Jacob 2004).

Many studies have ascertained the compositions and PT conditions of equilibration of the dominant phases, but relatively little work has been done on the phases formed when these products of subducted lithosphere are effected by alterations in P-T conditions immediately prior to, and during, transportation from depth by the host kimberlites. The almost-ubiquitous presence, around the primary garnet and clinopyroxene, of coronae containing low PT phases, such as plagioclase, mica and amphibole, indicates that most eclogites have partially readjusted to post-peak metamorphism conditions. In the present study the main aim has been to document three types of arrested re-equilibration.

Eclogites have been classified in different ways. One classification, on textural grounds, defined Group I as characterised by rounded garnet surrounded by pyroxene (interpreted as arising during accumulation from an igneous parent); and Group II in which equant garnet, often with planar faces, and clinopyroxene have an interlocking fabric (MacGregor and Carter 1970). These differences were suggested as being accompanied by chemical differences, with more $\mathrm{Cr}_{2} \mathrm{O}_{3}, \mathrm{CaO}, \mathrm{FeO}$ and $\mathrm{MnO}$ in the clinopyroxene and more $\mathrm{MgO}, \mathrm{NiO}, \mathrm{Li}_{2} \mathrm{O}$ and $\mathrm{Na}_{2} \mathrm{O}$ in the garnets in Group I eclogites. McCandless and Gurney (1989) proposed an alternative classification, independent of texture, based on the sodium content of garnet $\left(\mathrm{Na}_{2} \mathrm{O}\right.$ $\geq 0.09$ wt\% Group I garnet and less ) and the potassium content of clinopyroxene $\left(\mathrm{K}_{2} \mathrm{O}\right.$ is $\geq 0.08$ wt $\%$ in Group I pyroxene and less in Group II). A secondary objective of the present study is to examine the chemical vs textural classification of the three eclogites concerned.

Sample descriptions and mineral chemistry

Sample 1. Kyanite-corundum eclogite BD2745 is from kimberlite pipe137-K1, one of a small cluster of pipes centred on $10^{\circ} \mathrm{S} 19^{\circ} \mathrm{E}$ in the Chicundo area of Angola. Garnet and pyroxene comprise $\sim 95 \%$ of the rock by volume and texturally the rock is a group II eclogite Mineral compositions in this and the other specimens were analysed on a Camebax Microbeam electron microprobe at the University of Edinburgh, by routine WDS techniques but $\mathrm{Na}$ and $\mathrm{K}$ were analysed early in theroutine to avoid volatility/migration effects
The garnet has proved to be zoned, though the boundary between the core garnet and that forming the rim is sharp. The pyroxene is extensively altered with bright green relict cores set in a fine-grained whitegrey matrix of secondary pyroxene intergrown with plagioclase. Kyanite is in rounded grains up to $1 \mathrm{~mm}$ in length and equant rutile grains are up to $1 \mathrm{~mm}$ in size. The rock is cut by thin $(0.5$ to $1 \mathrm{~mm})$ sub-parallel veinlets containing glass, plagioclase, phlogopite, a barian silicate and rare apatite. Adjacent to the veins, some kyanite grains are marginally lmelted and replaced by acicular corundum, the texture of which suggests rapid quenching (Fig. 1). Some quench corundum grains are intergrown with plagioclase

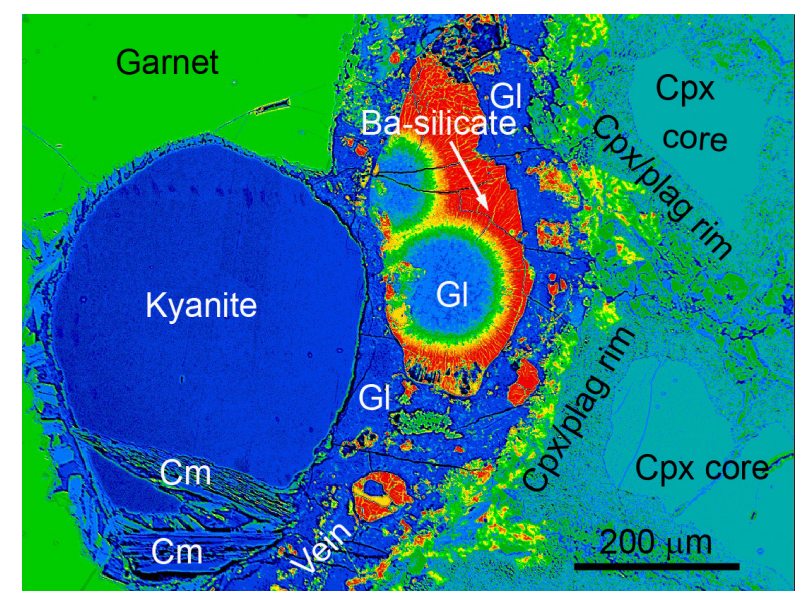

Fig.1. False-colour image of primary and secondary phases in Chicundo eclogite. Abbreviations: $\mathrm{Cm}$ corundum, Gl glass.

Garnet cores are calcic pyrope-almandine $\left(\mathrm{Ca}_{29} \mathrm{Mg}_{40}\right.$ $\left.\mathrm{Fe}_{31}\right)$ and rims are pyrope-grossular-almandine $\left(\mathrm{Ca}_{25}\right.$ $\mathrm{Mg}_{55} \mathrm{Fe}_{20}$ ); further differences are in $\mathrm{TiO}_{2}$ (core 0.06 , rim 0.32 wt \%) and $\mathrm{Na}_{2} \mathrm{O}$ (core 0.10 , rim 0.05 wt.\%). The clinopyroxene cores are omphacite and contain $\sim 5$ Ca-Eskola molecule, a characteristic of peraluminous eclogites in general. The omphacite contains no detectable $\mathrm{K}_{2} \mathrm{O}$ (unlike clinopyroxenes analysed by the same probe technique in other eclogites - below); this and low $\mathrm{Na}_{2} \mathrm{O}$ in garnet are in the ranges established by McCandless and Gurney (1989) for their Group II eclogites. The clinopyroxene in the coronas around the primary omphacite is sodic fassaite containing more diopside molecule but a lower jadeite content than the primary omphacite; in addition, like the rim on the garnet, it contains higher $\mathrm{MgO}$ and $\mathrm{TiO}_{2}$. Plagioclase intergrown with the corona pyroxene is $\mathrm{Ab}_{77.2}$ containing detectable $\mathrm{BaO}$ $(0.02 \mathrm{wt} \%)$. In the primary kyanite and the secondary 
corundum, the only additional significant oxide is iron, and the $\mathrm{Fe}_{2} \mathrm{O}_{3}$ content of the secondary corundum (which also contains appreciable $\mathrm{TiO}_{2}$ ) is $2 \mathrm{x}$ that in the kyanite. The rutile is slightly zoned with lower Fe and $\mathrm{Al}$ in grain rims compared with cores. With this exception, the phases rimming and replacing the main primary phases are consistently higher in $\mathrm{Fe}$ and $\mathrm{Ti}$.

In the veins, due to partial devitirifcation, the glass is of variable composition, but overall low in $\mathrm{SiO}_{2}$ (37-42 wt $\%)$ and high in $\mathrm{Al}_{2} \mathrm{O}_{3}$ (14-24\%) and $\mathrm{MgO}(18-27 \%)$; abundant microlites of plagioclase are of highly variable composition $\left(\mathrm{An}_{36-50}\right)$, with the more sodic grains occurring close to, or intergrown with, skeletal corundum. Vein mica is barian-titanian-phlogopite ( $\mathrm{BaO} 0.74$ wt.\%, $\mathrm{TiO}_{2} 2.93$ wt.\%, $\mathrm{Mg} /(\mathrm{Mg}+\mathrm{Fe})$ 0.90). An abundant vein phase is a $\mathrm{BaAl}$ silicate; analytical totals have a shortfall which, if due to un-analysed water (beam conditions were not adjusted for a mineral of such potential instability).suggests that the phase may be a zeolite, akin to harmotome.

Garnet core/omphacite vs garnet rim/fassaite thermometry of $887^{\circ} \mathrm{C} v s 1078^{\circ} \mathrm{C}$ (assumed pressure $30 \mathrm{~kb}$, T from Krogh 1988) indicates a temperature increase during the re-equilibration which would account for melting, as exemplified in the glassy veinlets, and the formation of corundum from kyanite. However, the presence of titanian phlogopite and harmotome in the veins indicates melting might have been partly metasomatically triggered, the mineralogy indicating addition of $\mathrm{K}, \mathrm{Ti}, \mathrm{Fe}, \mathrm{Ba}, \mathrm{P}$ and $\mathrm{OH}$. Although amongst the primary phases, Ti might have been sequestered in original rutile, and small amount of $\mathrm{K}$ in clinopyroxene, we do not find analysable $\mathrm{Ba}$ in our primary phases.

Sample 2. Eclogite BD4186-L78 is from the Lace kimberlite, one of a small group of kimberlites penetrating Karoo sediments and lavas 25-30 km NW of Kroonstadt, Orange Free State, South Africa. The rock is texturally a group II eclogite comprising approximately equal amounts of fresh red garnet cut by veins of secondary alteration products, and cores of fresh pyroxene which are surrounded by coronas mainly of secondary fine-grained acicular clinopyroxene (Fig. 2). There are no coronas at the contacts between pyroxene totally included within garnet and the host garnet, which suggests that the coronas are not due to garnet-pyroxene interaction.

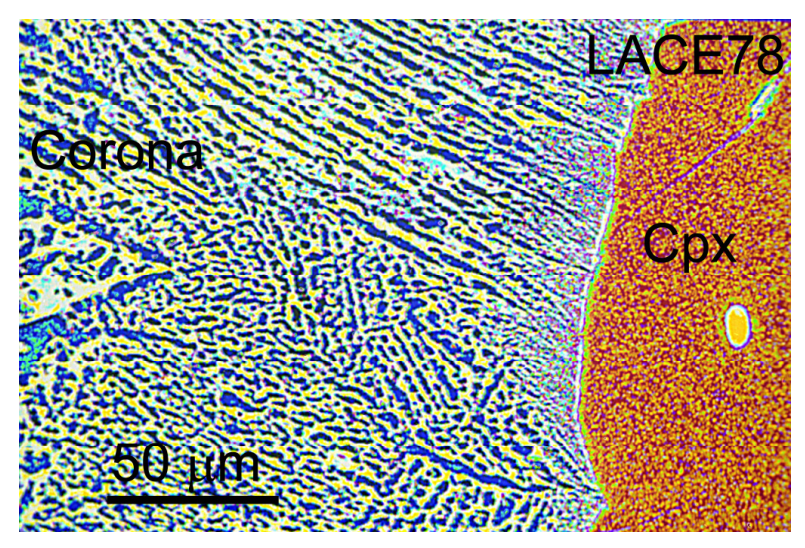

Fig.2. False-colour image of the corona, around primary clinopyroxene in Lace eclogite 78 (sample 2), dominated by secondary acicular cpx (yellow) interspersed with $\mathrm{K}$ feldspar and glass (blue).

The garnet is pyrope-grossular-almandine $\left(\mathrm{Ca}_{27} \mathrm{Mg}_{52} \mathrm{Fe}_{21} ; \mathrm{Na}_{2} \mathrm{O} 0.09\right.$ wt. $\left.\%\right)$ and the primary pyroxene is potassic omphacite $\left(\mathrm{K}_{2} \mathrm{O} 0.12 \mathrm{wt} \%, \mathrm{Na}_{2} \mathrm{O}\right.$ 6.8 wt. $\%, \mathrm{Al}_{2} \mathrm{O}_{3} 14$ wt. \%). The $\mathrm{Na}$ and $\mathrm{K}$ contents of the garnet and pyroxene, respectively, fall within the ranges for group I eclogites (McCandless and Gurney 1989). The acicular pyroxene surrounding the primary pyroxene is more augitic, being less sodic and aluminous $\left(\mathrm{Na}_{2} \mathrm{O} 2.4\right.$ to 3.2 wt.\%, $\mathrm{Al}_{2} \mathrm{O}_{3} \quad 7.6$ to 10.4 wt.\%) but more calcic and magnesian than the primary omphacite and it also contains less $\mathrm{K}_{2} \mathrm{O}$ (0.02 wt\%); the variable compositions suggest non-equilibrium This secondary pyroxene is intergrown with small amounts of potassic feldspar $\left(\mathrm{Or}_{93.9} \mathrm{Ab}_{5.7} \mathrm{An}_{0.4}\right.$ ) and alkali-rich glass $\left(\mathrm{K}_{2} \mathrm{O} 0.5\right.$ to $0.9 \mathrm{wt} \%, \mathrm{Na}_{2} \mathrm{O} 3.2$ to $\left.5.7 \mathrm{wt} \%\right)$, the presence of feldspar intergrown with low- $\mathrm{K}$ corona pyroxene indicating response of the original K-bearing omphacite to reduced pressure (Erlank and Kushiro 1970, Harlow 1997).

At an assumed $30 \mathrm{~kb}$, the initial equilibration was at $999^{\circ} \mathrm{C}$ (Krogh 1988). There are no experimental data that might constrain the conditions of re-equilibration. During re-equilibration the original omphacite has lost alkalis and alumina, but increase in the $\mathrm{TiO}_{2}$ content of the secondary diopside and its presence in the glass indicate that the re-equilibration was not isochemical

Sample 3. Another eclogite from Lace (BD4186-L70) contains rounded garnet in a matrix of clinopyroxene (textural Group I). The rock is overall more magnesian than sample 2. The calcic pyrope-almandine garnet $\left(\mathrm{Ca}_{10} \mathrm{Mg}_{67} \mathrm{Fe}_{23} ; \mathrm{Cr}_{2} \mathrm{O}_{3} \quad 0.15 \mathrm{wt} \%\right)$ lies at the more magnesian end of the range established for this type of garnet (Dawson and Stephens 1975). The clinopyroxene is a diopside with smaller amounts of $\mathrm{Na}_{2} \mathrm{O}(2.13$ wt $\%), \mathrm{Al}_{2} \mathrm{O}_{3}$ (2.61 wt $\left.\%\right)$ and $\mathrm{K}_{2} \mathrm{O}(0.01$ $\mathrm{wt} \%$ ), than.omphacite in sample 2 . The soda content of the garnet lies within the chemical range of McCandless and Gurney's (1989) group I eclogites, but the potash content of the diopside $(0.02 \mathrm{wt} \%)$ does not. Garnet is surrounded and separated from the diopside by thin (0.1-0.2 mm) coronae of websterite paragenesis - diopside, orthopyroxene and magnesian spinel $(\mathrm{mg}$ $\left.0.66, \mathrm{Al}_{2} \mathrm{O}_{3} 58.3 \mathrm{wt} \%\right)$. The orthopyroxene ( $m g 0.84$ ) is high in $\mathrm{Al}_{2} \mathrm{O}_{3}(7.9 \mathrm{wt} \%)$ and $\mathrm{CaO}$ (2.5 wt\%), an unusual combination also found in inclusions in diamond from the Monastery mine by Moore and Gurney (1989) who note that, as in sample 3, orthopyroxene with this high alumina content should not be in equilibrium with garnet. High-alumina opx (though not necessarily with high $\mathrm{CaO}$ ) is also found in bronzites from magnesian granulites, also including ultra-high temperature sapphirine-quartz granulite xenoliths from the Lace Mine (Dawson and Smith 1987). Reaction rim clinopyroxene has essentially the same composition as the primary clinopyroxene. Initial equilibration was at $974^{\circ} \mathrm{C}$ (assumed $\mathrm{P} 30 \mathrm{~kb}$ ). The high-Al of the corona pyroxenes (particularly the 
orthopyroxene) precludes calculation of the reequilibration temperature from the two-pyroxene solvus (see Carswell and Harley 1990.

During the retrogression, the garnet + clinopyroxene $\rightarrow$ opx + clinopyroxene + spinel reaction

was essentially isochemical; and the main chemical readjustment has been replacement of garnet by $\mathrm{Al}-$ bronzite+spinel. The presence of "granulite-facies orthopyroxene" indicates downgrading from eclogiteto granulite-facies conditions.

\section{Discussion}

1. Corundum, K-feldspar and orthopyroxene have been hitherto been reported as rather rare, but wellequilibrated, primary phases in eclogites. In the present study these phases occur in un-equilibrated parageneses resulting from breakdown of primary minerals due to heating (proven) and pressure decrease (inferred). During these arrested retrograde reactions the primary phases have been incompletely degraded and, combined with no visible re-annealing of the new assemblages, suggests that the period of retrogression was short. This, combined with evidence for metasomatism in two of the samples, is most plausibly linked to entrainment and rapid transport in the host kimberlites.

2. With reference to classification by the $\mathrm{Na}$-in garnet/K-in-clinopyroxene scheme (McCandless and Gurney, 1989), for sample 1 , the $\mathrm{Na}_{2} \mathrm{O}$ in the primary core of the garnet $(0.10 \mathrm{wt} \%)$ would classify the rock as a group I eclogite whereas the 0.05 wt. $\%$ in the garnet rim falls within the range for group II; the absence of $\mathrm{K}_{2} \mathrm{O}$ in the omphacite gives a group 2 classification.. Hence it appears that, in this sample, the retrogression (heating) together with the inferred metasomatism can change the compositional parameters for classification. For sample 2, both chemical parameters are consistent with a group I eclogite, though texturally it is a group II eclogite. In sample 3 , the soda content $(0.10 \mathrm{wt} . \%)$ of the garnet lies within the chemical range for group I eclogites, but the potash content of the diopside $(0.02 \mathrm{wt} \%)$ does not. 3. Based on whole rock analyses, Haggerty et al. (1993) suggest that anomalously-high amounts Ba, Ce, $\mathrm{P}, \mathrm{K} \mathrm{Sr}, \mathrm{Zr}$ and $\mathrm{Ti}$ are intrinsically characteristic of kimberlite-transported eclogites, Further, McCormick et al (1984) suggest the $\mathrm{Ba}$ and $\mathrm{K}$ was released from originally high $\mathrm{P}$ clinopyroxene. In the veins in sample 1 we found significant quantities of a barian silicate, the phlogopite contains $0.74 \mathrm{wt} \% \mathrm{BaO}$ and the glass contains up to 1.96 wt. $\% \mathrm{BaO}$ and 0.72 wt. $\% \mathrm{~K}_{2} \mathrm{O}$. In the primary phases, (at the detection limits of our eletronprobe which detected $\mathrm{K}$ in in cpxs in the other samples) we found no no $\mathrm{BaO}$ or $\mathrm{K}_{2} \mathrm{O}$ in pyroxene. Hence we propose that these elements, together with $\mathrm{P}$ and $\mathrm{OH}$ were introduced and would point out the coincidence between this introduction and a thermal event. Moreover, since K, Ba, P and the other elements highlighted by Haggerty et al. (1993) are characteristically enhanced in kimberlites (Wedepohl and Muramatsu 1979) we suggest the metasomatism and linked heating took place during entrainment and/or transport in the host kimberlite.

\section{References}

Carswell, D.A., Harley. S.L. 1990. Mineral barometry and thermometry. In: Carswell, D. A. (Ed.), Eclogite facies rocks. Blackie, Glasgow, pp. 83-110.

Dawson,J.B., Stephens, W.E. 1975. Statistical classification of garnets from kimberlite and associated xenoliths. J. Geol. 83, 589-607.

Dawson, J.B., Smith, J.V. 1987. Reduced sapphirine granulite xenoliths from the Lace kimberlite, South Africa: implications for the deep structure of the Kaapvaal craton. Contrib.Mineral Petrol. 95, pp.376-383.

Erlank, A.J., Kushiro, I. 1970. Potassium contents of synthetic pyroxenes at high temperatures and pressures. Carnegie Inst. Wash yearbook 68, 439442.

Haggerty, S.E., Fung, A.T., Pyle, J.M. 1993. The mantle array and geochemistries of high pressure and high temperature eclogite from the West Africa (Koidu) and Kaapvaal (Jagersfontein) cratons. Russian Geol. Geophys. 34, 51-65.

Harlow, G.E. 1997. K in clinopyroxene at high pressure and temperature: An experimental study. Amer.Mineral. 82, 259-269.

Jacob, D.E., 2004. Nature and origin of eclogite xenoliths from kimberlites. Lithos 77, 295-316

Krogh E.J. 1988. The garnet-clinopyroxene $\mathrm{Fe}-\mathrm{Mg}$ geothermometer - a reinterpretation of existing experimental data. Contrib.Mineral Petrol. 99, 7580.

MacGregor, I.D., Carter, J.L. 1970. The chemistry of clinopyroxenes and garnets of eclogite and peridotite xenoliths from the Roberts Victor Mine, South Africa. Phys.Earth Planet. Int. 3, 391-397.

McCandless, T., Gurney, J.J. 1989. Sodium in garnets and potassium in clinopyroxene: criteria for classifying mantle eclogites. . In: Kimberlites and related rocks, Vol.2 Their mantle/crust setting, diamonds and diamond exploration. Geol Soc.Australia Spec. Publn 14. Blackwells, Carlton, pp. 827-832

McCormick,T.C., Smyth, J.R. and Caporuscio, F.A. 1994. Chemical systematics of secondary phases in mantle xenoliths. In: Meyer, H.O.A. and Leonardos, O.H. (Eds.), Kimberlites, related rocks and mantle xenoliths (Proc.Vol.1, $5^{\text {th }}$ Internat. Kimberlite Conf. Brazil), Compania de Pesquera de Recursos Minerais, Rio de Janeiro, pp.405-419.

Wedepohl, ,K.H. , Muramatsu, Y. 1979. The chemical compositions of kimberlites compared with the average compositions of three basaltic magma types. In: Boyd, F.R., Meyer, H.O.A. (Eds.) Kimberlites, diatremes and diamonds: their geology, petrology and geochemistry. Amer. Geophys. Union, Washington, D.C., pp. 300-312. 
